Summer 2015

\title{
Surviving the Crisis and Austerity: The Coping Strategies of Portuguese Households
}

\author{
Catarina F. Frade \\ University of Coimbra, cfrade@fe.uc.pt \\ Lina Coelho \\ University of Coimbra, Icoelho@fe.uc.pt
}

Follow this and additional works at: https://www.repository.law.indiana.edu/ijgls

Part of the Family, Life Course, and Society Commons, International Law Commons, and the Social Welfare Law Commons

\section{Recommended Citation}

Frade, Catarina F. and Coelho, Lina (2015) "Surviving the Crisis and Austerity: The Coping Strategies of Portuguese Households," Indiana Journal of Global Legal Studies: Vol. 22 : Iss. 2 , Article 11.

Available at: https://www.repository.law.indiana.edu/ijgls/vol22/iss2/11

This Symposium is brought to you for free and open access by the Law School Journals at Digital Repository @ Maurer Law. It has been accepted for inclusion in Indiana Journal of Global Legal Studies by an authorized editor of Digital Repository @ Maurer Law. For more information, please contact rvaughan@indiana.edu.

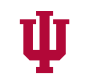

JEROME HALL LAW LIBRARY

INDIANA UNIVERSITY Maurer School of Law
Bloomington 


\title{
Surviving the Crisis and Austerity: The Coping Strategies of Portuguese Households
}

\author{
CATARINA FRADE* $\&$ LINA COELHO ${ }^{* *}$
}

\begin{abstract}
In recent years, Southern European households have been facing acute economic hardship involving falling incomes, rising unemployment, devalued investment portfolios, and a growing burden of debt. This means most households have been forced to make unusual adjustments to their expenditure and living standards. However, Portuguese society has revealed the capacity to deal with austerity through the way households are resorting to self-mobilization and solidarity-based strategies. These adjustment strategies are inscribed in a cultural framework in which familial values, prevalent in Southern European societies, stand out in supporting a strong, operative welfare society. This feature is confirmed hereby through empirical research on the coping mechanisms mobilized by households, via survey questionnaire and interview techniques.
\end{abstract}

\section{INTRODUCTION}

Portugal has been severely hit by a prolonged economic crisis. From 2008 to 2013 , the average per capita gross domestic product (GDP) shrank by more than 6.5 percent (compared with -2.4 percent in the European Union as a whole), ${ }^{1}$ the unemployment rate rose by around eight percentage points to the highest figure ever recorded (17 percent

* Assistant Professor of Law, Faculty of Economics of the University of Coimbra and Researcher of the Centre for Social Studies.

** Assistant Professor of Economics, Faculty of Economics of the University of Coimbra and Researcher of the Centre for Social Studies.

1. See European Commission's Directorate General for Economic and Financial Affairs, AMECO, http://ec.europa.eu/economy_finance/ameco/user/serie/SelectSerie.cfm (AMECO is the annual macro-economic database of the European Commission's Directorate General for Economic and Financial Affairs).

Indiana Journal of Global Legal Studies Vol. 22 \#2 (Summer 2015)

(C) Indiana University Maurer School of Law 
in 2013), and the downward trend in the poverty rate reversed..$^{2}$ Like Greece, Ireland, and Spain, Portugal experienced the harmful effects of a sovereign debt crisis in addition to the harmful effects resulting from the international financial crisis of 2008 . The combined effects of the two crises deepened the economic stagnation that had been evident since the beginning of the 2000 s, halting the nation's ability to catch up with the average European Union per capita income. ${ }^{3}$ The economic vulnerability of the country, resulting from stagnation in growth combined with rising levels of public and private foreign debt, inevitably led to a request for economic and financial assistance from the European Central Bank, the European Commission, and the International Monetary Fund (the Troika). The assistance would allow Portugal to avoid seeking the prohibitively expensive resources of the global financial market. ${ }^{4}$

Within such a recessive environment, most households have been forced to make remarkable adjustments to their expenditure budgets and living standards. Surprisingly, Portugal has been keeping a remarkably low level of credit arrears in a cross-country comparison. ${ }^{5}$

2. See Press Release, Statistics Portugal, Unemployment Rate at $17.7 \%$ - 1st Quarter 2013 (May 9, 2013), available at http://www.ine.pt/xportal/xmain?xpid= INE\&xpgid=ine_destaques\&DESTAQUESdest_boui $=151972007 \& D E S T A Q U E S t e m a=541$ 4314\&DESTAQUESmodo=2; Press Release, Statistics Portugal, Income and Living Conditions (Mar. 24, 2014), available at http://www.ine.pt/xportal/xmain?xpid=INE \&xpgid=ine_destaques\&DESTAQUESdest_boui $=208819520 \& D E S T A Q U E S m o d o=2 \& x l a n$ $\mathrm{g}=\mathrm{en}$ (Statistics Portugal is the public institution responsible for producing and disseminating official statistical information).

3. See BAnCo De Portugal, ANNUAL Report: The Portuguese Economy, 79 (2014), available at http://www.bportugal.pt/en-US/PublicacoeseIntervencoes/Banco/RelatConsel hoAdministracao/Pages/default.aspx.

4. A financial assistance programme, amounting to $€ 78$ billion over a three-year period, was agreed in May 2011. The programme was made conditional on fiscal consolidation measures and structural reforms, described in detail in the so-called "Memorandum of Understanding" and its subsequent updates. See, Economic and Financial Assistance Programme, BANCO DE PORTUGAL, http://www.bportugal.pt/enUS/EstabilidadeFinanceira/AEstabilidadeFinanceiraPAEF/OProgramaAssistenciaFinance iraPortugal/Pages/inicio.aspx (last visited Feb. 13, 2015) (describing the Portuguese Economic and Financial Assistance Programme, including the austerity measures, the monitoring of their enforcement and the final assessment of the Programme); see also INTERnational Labour Organization, Portugal: TACKLING the JOBS CRISIS IN PORTUGAL (2014) (providing an in-depth analysis of the job crises in Portugal).

5. See Arrears on Mortgage or Rent Payments, EuRostat, http://appsso.eurostat.ec. europa.eu/nui/show.do?dataset=ilc_mdes06\&lang=en (last updated Jan. 14, 2015); Arrears on Utility Bills, EUROSTAT, http://appsso.eurostat.ec.europa.eu/nui/show.do?dataset=ilc_ mdes07\&lang=en (last updated Jan. 14, 2015); Arrears on Hire Purchase Instalments or Other Loan Payments, EUROSTAT, http://appsso.eurostat.ec.europa.eu/nui/show.do? dataset=ilc_mdes08\&lang= (last updated Jan. 14, 2015). 
We argue that the main reason for this seemingly paradoxical situation arises from the familistic tradition that underpins a pervasive welfare society. ${ }^{6}$ Families play a central role as social protection providers in Portugal, as intergenerational kinship ties and networking are stronger compared to other non-Southern European countries. This implies that intergenerational solidarity plays a decisive role in keeping a minimum social safety net. ${ }^{7}$

Analyzing the coping strategies employed by Portuguese households during the current economic crisis enables us to discuss the crucial role of social support networks, which are the key element in understanding the nondisruptive process of adjustment observed in Portugal. The findings of this research have broad explanatory potential given the cultural, economic, and social model Portugal shares with other Southern European countries affected by the financial crisis and austerity.

The interpretative framework used in this paper draws on Frade's typology ${ }^{8}$ concerning the strategies adopted by Portuguese households to cope with the consequences of financial hardship. The assessment of households' coping strategies is based on a transdisciplinary empirical study involving quantitative and qualitative methods. A sample of working-age couples with children participated in the survey. In addition, couples sharing the same profile took part in extensive interviews.

6. See generally Sílvia Portugal, Famílias E Redes Sociais: Ligaçōes Fortes Na PRODUÇÃO DE BEM-ESTAR (2013) (studying the role family networks play in providing welfare services in Portugal); Robert M. Milardo, Theoretical and Methodological Issues in the Identification of the Social Networks of Spouses, 51 J. MARRIAGE \& FAM. 165 (1989) (analyzing the two main methods of identifying social networks); Boaventura de Sousa Santos, The Welfare State in Portugal: Between Conflicting Globalizations (Mar. 1, 1999) (paper presented at the Center for European Studies, Harvard University), available at http://www.ces.uc.pt/publicacoes/oficina/ficheiros/140.pdf (describing the evolution of welfare policies in Portugal); Boaventura de Sousa Santos, State, Wage Relations and Social Welfare in the Semiperiphery: The Case of Portugal, OFICINA Do CES (Centro de Estudos Sociais, Universidade de Coimbra), Jan. 1991, available at http://www.ces.uc.pt/ publicacoes/oficina/ficheiros/23.pdf (defining Portugal as a semiperipheral society and describing the ramifications of this position); Pedro Hespanha \& Ana Isabel Alves, $A$ Construção da Habitação em Meio Rural: Um Domínio da Sociedade-Providência, 42 REVISTA CRITICA DE CIÉnCIAS SOCIAIS 125, 125 (1995).

7. See European Comm'N, Facing the Crisis: The Coping Strategies of UNEMPLOYED PEOPLE IN EUROPE 41-44 (2014), available at http://ec.europa.eu/social/ main.jsp?catId $=738 \&$ langId=en\&pubId $=7729$.

8. See Centro de Estudos Sociais da Universidade de Coimbra, Desemprego E SOBREENDIVIDAMENTO DOS CONSUMIDORES: CONTORNOS DE UMA 'LIGAÇÃo PERIGOSA' 10 (Catarina Frade ed.) (2006), available at $\mathrm{http}: / /$ www.ces.uc.pt/myces/UserFiles/livros/453 433_relatorio_desemprego_sobreendividamento\%255B1\%255D.pdf [hereinafter Frade]. 
This text is organized into three sections. The first section characterizes the effects of the crisis and austerity on households' standards of living on an aggregated scale. The second part draws on Frade's theoretical framework, comprising the interpretative grid that supports both the analysis and structuring operative concepts. In the third and final part, the results of the empirical research are presented and discussed.

\section{THE 'MACRO IMPACTS' OF THE ECONOMIC CRISIS AND AUSTERITY MEASURES ON HOUSEHOLD STANDARDS OF LIVING}

Portuguese households suffered from the economic slowdown itself and, in particular, from the fiscal adjustment measures adopted by the government to reform public finances. The fiscal policy measures adopted include: reforms to the labor market (changes in labor law to foster flexibility and changes to the terms of collective agreements); wage cuts and reductions in the number of civil servants; cuts to public benefits (particularly, pensions and unemployment benefits); increased taxes in income, turnover, and property; and cuts in public contributions to healthcare, education, and transport. ${ }^{9}$

The sharp growth in unemployment has disproportionately affected young people and those with low levels of education. In the fifteen to twenty-four age group, unemployment rose from 16.6 percent in 2007 to 37.7 percent in 2013. ${ }^{10}$ In the same period, employment rates fell by 9.5 percentage points for men and 5.1 percentage points for women.11 In addition, long-term unemployment increased dramatically from 48 percent in 2008 to 62 percent in 2013.12 In February 2013, 13,187 couples were registered as having both members unemployed-two and a half times more than at the end of 2011 . Worsening conditions in the labor market have also triggered emigration: between 2007 and 2012, the number of permanent emigrants increased sixfold, with young people, particularly the most highly qualified, overrepresented in the emigrant population. ${ }^{13}$

9. See Economic and Financial Assistance Programme, supra note 4.

10. See generally STATISTICS PORTUGAL, http://www.ine.pt/xportal/ xmain?xpid=INE\&xpgid=ine_publicacoes (last visited Feb. 28 2015) (containing resources on the statistics of Portugal) (long-term unemployment is defined as being without work for over one year).

11. See id.

12. See id.

13. See International Labour ORganization, supra note 4 , at 14 . 
When referred to the anchored poverty line, ${ }^{14}$ the poverty rate ${ }^{15}$ increased by 6.9 percentage points between 2009 and 2012, ranking Portugal as the third worst performer among the $28 \mathrm{EU}$ member states. The rise in poverty rates affected mostly people of working age, children, and young people. Families with more children were particularly affected. In contrast, poverty increased only marginally among the elderly. ${ }^{16}$ Although 10 percent of the working population lives below the poverty line, losing employment has been one of the main reasons why households have suffered income losses; in 2012, 40 percent of the unemployed population lived below the poverty linemore than double the overall poverty rate. ${ }^{17}$

Consolidation of public finances in the second phase of the crisis resulted in significant cuts to social security expenditure, leaving a large number of unemployed workers without protection. According to Gallie and Paugam, in 2000 the Portuguese social protection system was already a "sub-protector" system; consequently, the changes undertaken during the financial assistance program settled with the Troika worsened the situation. ${ }^{18}$ Between 2001 and 2011, the effective coverage rate of unemployment insurance decreased from 82.9 percent to 44.8 percent. ${ }^{19}$ Moreover, the activation rate-the proportion of the unemployed benefiting from active employment policies-was quite low within the context of the European Union (18 percent in 2011). ${ }^{20}$

Besides, public expenditure on family benefits remains relatively weak, amounting to only 1.5 percent of the GDP, compared to an Organization for Economic Cooperation and Development (OECD)

14. This fixes the real value of the poverty threshold at 2009 levels and then adjusts only for inflation.

15. People at risk-of-poverty are those with an equivalent disposable income below the risk-of-poverty threshold, which is set at $60 \%$ of the national median equivalised disposable income (after social transfers). See Income and Living Conditions, Statistics Illustrated, EUROSTAT, http://ec.europa.eu/eurostat/web/income-and-living-conditions/ statistics-illustrated (last visited Feb. 28 2015).

16. See Income and Living Conditions, Database, EUROSTAT, http://ec.europa.eu/ eurostat/web/income-and-living-conditions/data/database (last visited Feb. 28 2015) [hereinafter Database].

17. See BANCo DE PoRTugaL, supra note 3 , at 88.

18. Duncan Gallie \& Serge Paugam, The Experience of Unemployment in Europe: The Debate, in WELFARE REgIMES AND THE EXPERIENCE OF UNEMPLOYMENT IN EUROPE 1, 9 (Duncan Gallie \& Serge Paugam, eds., 2000).

19. Pedro Adão e Silva \& Mariana Trigo Pereira, As Políticas de Proteção No Desemprego em Portugal, 70 Sociologia, Problemas E Práticas 133, 137 (2012).

20. See EuROPEAN COMM'N, supra note 7, at 11. 
average of 2.3 percent. ${ }^{21}$ The impact of social programs (excluding pensions) in reducing the risk of poverty decreased from 8.5 percentage points in 2009 to 6.8 percentage points in $2012 .{ }^{22}$

Even workers with more stable and secure jobs, particularly civil servants, have suffered major cuts to their income. ${ }^{23}$ According to PricewaterhouseCoopers, between the beginning of 2011 and the end of 2013 , the average public employee lost the equivalent of 3.7 net salaries. ${ }^{24}$ Taken together, wage and pension cuts, combined with increased taxation (including extraordinary income surtaxes and reduced tax exemption), have led to a sharp fall in standards of living, which has been particularly acute for the middle class. Inevitably, these adverse economic conditions have had a negative effect on the financial solvency of households.

For the two decades prior to the crisis, household debt had increased very rapidly: the debt rate, ${ }^{25}$ which represented only 20 percent of disposable income in 1990, rose to 40 percent in 1995 and 124 percent in 2009. ${ }^{26}$ Household credit was mainly for housing purposes. This increase in household debt meant low risk, since it took place in a favorable economic climate with steady growth in real wages and a steady fall in interest rates. Consequently, it represented a rational response by households to the political-economic context.27 Nevertheless, indebtedness made households more vulnerable to personal circumstances that could undermine their financial stability and the

21. See ORg. FOr ECON. COOPERATION AND Dev., OECD ECONOMIC SuRveYS PORTUGAL: OVERVIEW 34 (2014), available at http://www.oecd.org/economy/surveys/ Portugal-2014-Overview-Eng.pdf.

22. See Database, supra note 16.

23. See Economic and Financial Assistance Programme, supra note 4.

24. See Catarina Almeida Pereira, Funcionário médio perdeu quase quatro salários em três anos, JoRNAL NEGOCIOS, Jan. 17, 2014, at 18, available at http://www.mynetpress. com/pdf/2014/janeiro/2014011735d3f5.pdf.

25. Indebtedness is understood to mean the balance owed by a household, which may result from a single credit commitment or more than one commitment at the same time, in which case it is referred to as multi-indebtedness. See MARIA MANUEL MARQUES ET AL., O ENDIVIDAMENTO DOS CONSUMIDORES 1 (2000).

26. Luísa Farinha \& Sara Noorali, Endividamento e Riqueza das Famílias Portuguesas, in RELAtório de EstabildDade FinanCeira 145 (Banco de Portugal ed., 2004), available at http://www.bportugal.pt/pt-PT/BdP\%20Publicaes\%20de\%20Investigao/ AR200402_p.pdf; Catarina Frade \& Mariana Almeida, Portugal, in THE OVERINDEBTEDNESS OF EUROPEAN CONSUMERS: A VIEW FROM SIX COUNTRIES 66, 68 (Irina Domurath et al. eds., 2014), available at http://hdl.handle.net/1814/32451.

27. See generally Cláudia Abreu Lopes, Catarina Frade \& Fernanda Jesus, The Ultimate Victims of the Economic Crisis: A Portrait of Portuguese Overburdened Families, in CONTEMPORARY ISSUES IN CONSUMER BANKRUPTCY 147 (Wolfram Backert et al. eds., 2013) (detailing the problem of over-indebtedness in Portugal through surveys and interviews); BANCO DE PORTUGAL, supra note 3. 
reimbursement of debts. ${ }^{28}$ Thus, the rising unemployment, combined with the shrinking welfare state, favoured an increase in credit defaults and a growing number of bankruptcies. ${ }^{29}$ The statistical trend for personal bankruptcies reveals a perfect match with the negative impacts of the crisis and austerity. Personal bankruptcies increased by over 2000 percent between 2007 and $2013 .{ }^{30}$ In 2011, the number of individual persons' bankruptcies exceeded business bankruptcies for the first time. ${ }^{31}$ Nevertheless, in cross-national terms the figures for Portuguese household defaults have remained relatively low, given the high level of indebtedness and the serious financial constraints. According to European Union Statistics on Income and Living Conditions (EU.SILC) data, arrears on mortgage or rent payments, utility bills, and hire-purchase installments of Portuguese households are in line with the average EU-28 figures. ${ }^{32}$

\section{COPING WITH THE CRISIS IN THE CONTEXT OF THE SHRINKING WELFARE STATE}

\section{A. Coping as an Operative Concept}

The concept of coping strategies will be used to explore the impact of the crisis and austerity policies on households. This concept has mainly been used in the fields of health psychology and sociology to address the

28. See generally Lopes, Frade \& Jesus, supra note 27.

29. According to the Bank of Portugal, the ratio of overdue household loans increased from $2.9 \%$ in December 2009 to $4.5 \%$ in December 2013. By the same token, the percentage of borrowers in households with overdue loans during the same period rose from $13.2 \%$ to $14.8 \%$. BANCO DE PoRTUGal, Boletim Estatístico, 130-31 (2014), available at http://www.bportugal.pt/pt-PT/Estatisticas/PublicacoesEstatisticas/BolEstatistico/ BEAnteriores/Lists/FolderDeListaComLinks/Attachments/173/BENov14.pdf.

30. Figures obtained from calculations based on quarterly statistical information issued by Direcção-Geral da Política de Justiça. DiRECção-GERAL DA POLf́tiCa DE JUSTIÇA, ESTATÍSTICAS TRIMESTRAIS SOBRE PROCESSOS DE FALÊNCIA, INSOLVÊNCIA E RECUPERAÇÃO DE EMPRESAS E SOBRE PROCESSOS ESPECIAIS DE REVITALIZAÇĀO (2007-2014) 1 (2014) available at $\mathrm{http}: / / \mathrm{www} . d g p j . m j . p t / s e c t i o n s / s i e j \_p t / d e s t a q u e s 4485 /$ estatisticas-trimestrais 8246/downloadFile/file/Insolvencias_trimestral_20141030.pdf. It should, however, be noted that in absolute terms the number of individuals in situations of insolvency is very modest, given the overall situation in the country. In cumulative terms, between 2008 and $2013,32,294$ bankruptcies of natural persons were registered.

31. See id. at 3 fig. 5.

32. The figures for arrears in 2012 are: $6.3 \%$ for Portugal and $10 \%$ for the EU-28 for utility bills; $4.8 \%$ for Portugal and $3.9 \%$, for EU-28 for mortgage or rent payments; $3.1 \%$ both for Portugal and the EU-28 for hire purchase instalments or other loan payments. Arrears on Utility Bills, supra note 5; Arrears on Mortgage or Rent Payments, supra note 5; Arrears on Hire Purchase Instalments or Other Loan Payments, supra note 5. 
way individuals deal with illness and stress in general. ${ }^{33}$ Its influence later extended to other spheres, such as the sociology of family ${ }^{34}$ and gender studies, ${ }^{35}$ and to other problems, such as unemployment, ${ }^{36}$ the reconciliation between professional and personal-family life, ${ }^{37}$ financial difficulties, ${ }^{38}$ and poverty. ${ }^{39}$

According to Carver and Connor-Smith, "Coping is often defined as efforts to prevent or diminish threat, harm, and loss, or to reduce associated distress." 40 Coping strategies are therefore forms of behavior used to adapt and adjust to adverse conditions. ${ }^{41}$ In this paper, we

33. See Uta Gerhardt, Coping and Social Action: Theoretical Reconstruction of the LifeEvent Approach, 1 Soc. HEALTH \& ILLNESS 195 (1979). See generally Jørgen Elm Larsen \& John Andersen, University of Copenhagen \& Roskilde University, Nordic Sociological Conference, Coping Strategies in Low Income Households in Denmark: Do Lower Levels Assistance Improve Labor Market Inclusion? (2012) (transcript available at https:// notendur.hi.is/shj/Papers/Social\%20stratification\%20and\%20labour/Coping\%20strategies \%20in\%20low\%20income\%20households\%20in\%20Denmark\%20-\%20Nordic\%20Sociological $\% 20$ Conference\%202012.doc).

34. See generally Graham Crow, The Use of the Concept of 'Strategy' in Recent Sociological Literature, 23 Soc. 1 (1989) ("Analysis of actions and their outcomes in terms of strategies carries with it the promise of avoiding some of the pitfalls of the classic agency/structure dichotomy, as well as shedding a different light on questions of rationality.").

35. See generally Sílvia Portugal, Women, Welfare State, and Welfare Society in Portugal, in The Policies of ReProduction at the TURn of THE 21ST CenturY: The Cases of Finland, Portugal, Romania, Russia, Austria, and the US 41-54 (Maria Mesner \& Gudrun Wolfgruber eds., 2006) (examining the relationship between the state, the family, and the market in the social welfare crisis in Portugal at the turn of the 21st century).

36. See generally David Fryer \& Rose Fagan, Coping with Unemployment, 23 INT'L J. POL. ECON. 95 (1993) (describing the ways people cope effectively with unemployment).

37. See generally Jeff Hyman, Dora Scholarios \& Chris Baldry, Getting On or Getting By?: Employee Flexibility and Coping Strategies for Home and Work, 19 WORK EMP. \& Soc'Y 705 (2005) (studying the ways in which employees in call centres and the software sector balance their work and domestic lives). See generally Meg Luxton, Families and the Labour Market: Coping Strategies from a Sociological Perspective, in How FAMILIES COPE AND WHY POLICYMAKERS NeED TO KNOW 57 (David Cheal et al. eds., 1998) (examining how families cope with the contradictions created by the two labor processes: paid employment and unpaid domestic labor).

38. See generally Frade, supra note 8.

39. See generally Larsen \& Andersen, supra note 33.

40. Charles S. Carver \& Jennifer Connor-Smith, Personality and Coping, 61 ANN. REv. PSYCHOL. 679, 685 (2010).

41. Although some authors only include voluntary responses in the concept of coping, others also add involuntary or automatic responses. See Carver \& Connor-Smith, 2010, in which the authors summarise the main coping strategies and combine a more contextualised understanding of coping, as advocated by Lazarus \& Folkman (1984) in their transactional model, with another approach based more on personality traits, as argued by Carver, Scheier \& Weintraub (1989). See Charles S. Carver et al., Assessing Coping Strategies: A Theoretically Based Approach, 56 J. PERSONALITY \& SOC. PSYCHOL. 
consider coping strategies to be the formal and informal mechanisms adopted by individuals and families, in a relatively planned and deliberate way, to deal with the financial difficulties that are affecting their quality of life and personal, social, and professional well-being. ${ }^{42}$ Coping strategies include (a) strategic behavior, as active, usually longterm measures, and (b) adaptive behavior, as reactive measures, involving basic, usually short-term adjustments. ${ }^{43}$

Faced with financial difficulties, households tend to combine immediate with more weighted forms of behavior, and more pragmatic and intuitive measures with more planned and customized ones. Extant empirical research has shown that in the context of financial difficulties, households react by immediately cutting back on consumption. ${ }^{44}$ Adaptive behavior plays a key role in dealing with situations involving significant income losses, since it produces immediate effects. However, this is usually insufficient to deal with prolonged financial constraints. In such a case, a more planned and structured approach is required to reconfigure the expenditure pattern to a new (more restricted) one. The reconfiguration to a new, less affluent lifestyle may result from an imposition or suggestion of an external entity, such as the social services or the courts. In such cases it is still possible to detect an internal impulse in the act of seeking out aid.

Reconfiguring family spending habits is a painful process that requires making choices, prioritizing, and reshaping individual and common interests within the family sphere. ${ }^{45}$ Couples' financial decisions result from complex interactions involving tacit or explicit negotiation between the spouses. Financial austerity changes the assumptions behind those "negotiations," thus creating a context that can lead to (or rekindle) conflicts over the reallocation of scarcer financial resources. In this sense, the crisis represents a challenge and a threat, both to the stability and unity of the family and, in more serious cases, to its actual survival. It may be said that the crisis puts to the test the resilience of families.

267, 267 (1989). See generally RichaRd S. LAZARUS \& SUSAN FOLKMAN, STRESS, APPRAISAL, AND COPING (1984).

42. See Frade, supra note 8, at 201.

43. See generally Larsen \& Andersen, supra note 33.

44. See Frade, supra note 8 , at 214.

45. See generally Lina Coelho, My Money, Your Money, Our Money: Contributions to the Study of Couples' Financial Management in Portugal, 6 RCCS ANNUAL REVIEW 83 (2014) (studying household financial management in Portugal). 


\section{B. An Interpretative Grid for Coping Strategies}

We adopt here the interpretative grid proposed by Frade ${ }^{46}$ to understand how Portuguese households have sought to overcome the financial constraints caused by the financial crisis and the national austerity program. The strategies were classified according to the people and entities mobilized (i.e., convoked) by households to help them deal with their financial problems. ${ }^{47}$ According to the grid, households resort to three different types of coping strategies: "self-mobilization," corresponding to measures adopted by household members to reduce spending or increase income; "solidarity-based mobilization," involving aid from friends and close family members, in the good tradition of welfare societies; 48 and "institutional mobilization," including requests by individuals to the state (claims for social protection and assistance), civil society (especially nonprofit organizations), or the market, to overcome financial difficulties. While in self-mobilization, coping takes place within the inner circle; in solidarity-based and institutional mobilization, coping is sought outside the nuclear family (other relatives, friends and available social, economic, and legal mechanisms).

\section{Self-Mobilization}

In situations of financial constraint, members of the household first engage in dealing by themselves with the problems-self-mobilizationeither by downsizing consumption habits and lifestyles, seeking out new sources of income, or both.

Cutting down on goods and services is the strategy households adopt immediately. Besides cutting "superfluous" consumption, households reassess their consumer priorities and make an overall reduction in

46. See Frade, supra note 8 , at 201.

47. Various authors, particularly in the field of psychology, have identified and classified coping strategies in different ways. See Carver \& Connor-Smith, supra note 40. See generally Ellen A. Skinner et al., Searching for the Structure of Coping: A Review and Critique of Category Systems for Classifying Ways of Coping, 129 PsYCHOL. BuLL. 216 (2003). The classification used here follows a distinct sociological perspective and addresses the relational spheres of individuals and families. In this sense it comes close to an approach commonly used in sociological studies of network analysis, namely the egocentric approach. According to Sílvia Portugal, egocentric networks are defined as "the set of individuals who know and interact with a particular 'target' (an individual or couple)." See PORTUGAL, supra note 6, at 69. These types of networks give us a Ptolemaic vision of networks: rather than conceiving of them from the point of view of an external observer, we obtain the perspective of the individuals at their centre. See id.

48. See Boaventura de Sousa Santos, The Welfare State in Portugal: Between Conflicting Globalizations, 140 OFICINA DO CES 1, 17 (1999). 
spending. ${ }^{49}$ This reduction is distributed unequally in terms of goods and beneficiaries, since the tendency is to maintain spending on children as long as possible. The recognition by parents of their responsibility to provide for their children's well-being means that the needs of the children take precedence over any other. Adults are the first to give up certain expenses, although over time restrictions eventually affect all members of the household. Leisure (holidays and sports), culture (books and shows), and social events (going out with friends, eating out, or going to the cinema) are the items primarily given up or drastically reduced. Consequently, social ties start to break down, leading to feelings of depression and isolation, whilst also reducing the network of contacts that might, for example, help individuals find a new job. 50

Spending on food also tends to be adjusted, although in a less drastic manner than spending on leisure. A number of substitution strategies can be identified: reducing the consumption of certain more expensive products (meat and fish, for example) and increasing purchases of cheaper goods (cereals, bread, and vegetables); taking advantage of promotions and products from less prestigious brands (for example, "white label" products or own-brand goods); and shopping at discount stores, fairs, and markets rather than hypermarkets, shopping centers, and brand-name stores.

Adjustments in consumption of services refer, for instance, to cancelling particular services (cable television, internet, insurance), to searching for cheaper "packages," to giving up certain healthcare services, such as regular visits to the dentist, or to making greater use of public health services. Certain types of consumption traditionally segmented by gender, such as beauty treatments (hairdressers, cosmetics) or attending sport events are also cut drastically, if not completely given up.

As was already pointed out, reducing the quantity, range, and quality of what is consumed creates hardship and stress, leading to feelings of dissatisfaction and revolt (or the reverse, resignation). It is therefore a situation that may create or aggravate marital and family conflict.

In addition to reducing levels of consumption, self-mobilization is also pursued through income strategies. The most common, but also the most precarious of these, involves using personal savings. Households that manage to mobilize savings tend to put off or even avoid resorting

49. See EuRopean Comm'n, supra note 7, at 14-15.

50. See, e.g., EUROPEAN COMM'N, supra note 7, at 27, 28; PoRTUGAL, supra note 6; Frade, supra note 8. 
to other types of coping strategies. ${ }^{51}$ The existence of a financial "cushion" may provide the time needed for planning a more efficient strategy to survive the crisis and alleviate the sacrifices in consumption habits. ${ }^{52}$ Another measure is the search for a new job when unemployed. However, since it is not always possible to find a new job straight away, some individuals resort to small informal jobs, mostly in domestic cleaning, repairing, and building work. Extra working hours and a second job may also be part of this strategy. Another, more radical solution may require emigration in search of work or a better-paying job. Whilst working extra hours takes its toll on leisure and family time, emigration deeply affects family and friendship ties. In both cases, major changes may occur in the emotional and affective relations among household members. ${ }^{53}$

The extent of sacrifices and hardship faced by a household is shaped by objective factors such as accumulated wealth and disposable income, composition of the family (in particular, the presence of children), and place of residence (urban versus rural). Additionally, prevailing social values and individual perceptions on the causes and drivers of the crisis play a role. In research published in 2012, Lopes and Frade concluded that collective beliefs about the economic crisis and trust in political and market institutions influenced the willingness of individuals to make additional long-term sacrifices to their lifestyles, a finding that corroborates the Theory of Market Anomie. ${ }^{54}$

\section{Solidarity-Based Mobilization}

Solidarity-based mobilization entails mutual aid based on family and friendship networks. This operates according to a rationale of "gift

51. See Frade, supra note 8 , at 176.

52. See id. at 76 (concluding that a lack of savings combined with weak or non-existent solidarity-based networks made the unemployed more likely to become involved in situations of over-indebtedness).

53. See generally World Health Organization [WHO], Impact of Economic Crises on Mental Health (2011). See Adam Feibelman, Defining the Social Insurance Function of Consumer Bankruptcy, 13 ABI L. REv. 1, 41 (2005) (discussing the emotional stress caused by financial problems).

54. See Cláudia Abreu Lopes \& Catarina Frade, The Way into Bankruptcy: Market Anomie and Sacrifice Among Portuguese Consumers, 35 J. CoNSUMER POL'Y 477, 495 (2012). See generally Richard Rosenfeld \& Steven F. Messner, Markets, Morality, and an Institutional-Anomie Theory of Crime, in THE FUTURE OF ANOMIE THEORY 207 (Nikos Passas \& Robert Agmew eds., 1997). See also Felix Roth, The Eurozone Crisis and Its Effects on Citizens' Trust in National Parliaments, CENTRE FOR EUR. POL'Y STUD. COMMENT. 1, 3 (Dec. 8, 2010), http://www.ceps.eu/book/eurozone-crisis-and-its-effectscitizens\%E2\%80\%99-trust-national-parliaments. 
and reciprocity" following Marcel Mauss's perspective. ${ }^{55}$ Solidarity tends to play a key role in the financial and emotional well-being of individuals. ${ }^{56}$ The ability to mobilize informal solidaritybased networks reduces the risk of social exclusion and poverty for those who lack the necessary means to support themselves and live with dignity. ${ }^{57}$ By offering money, providing goods (food, clothing and footwear, housing), or giving services (childcare, domestic chores), family and friends alleviate the hardships faced by households. ${ }^{58}$ Empirical data highlights the particular importance of these networks among lower socioeconomic strata. ${ }^{59}$

Solidarity-based mobilization is a clear example of the so-called welfare society's central role in Southern European countries (Portugal, Spain, Italy, and Greece). "Welfare society" is understood here as "the networks of relationships of inter-knowledge, mutual recognition and mutual help based on kinship and community ties, through which small social groups exchange goods and services on a nonmarket basis and with a logic of reciprocity."60 In Southern Europe, the welfare society

55. See generally MARCEL MAUSS, THE GIFT: The FORM AND REASON FOR ExCHANGE IN ARCHAIC SociETIES (Routledge Classics 2002) (1950) (recognizing the gift as a central element of archaic societies, but also considering it a residual manifestation of the past in modern societies). See generally JACQUES T. GODBOUT, L'ESPRIT DU DON (La Découverte ed., 1992) (examining the nature of giving throughout history and in today's society); Alain CaIllet, ANTHRopologie du DON : Le Tiers Paradigme (Desclée de Brouwer ed., 2000) (expanding on Mauss's work and defining gift as the third paradigm of social relations).

56. See EUROPEAN COMM'N, supra note 7, at 41. See also Frances Woolley, Work and Household Transactions: An Economist's View, in HOW FAMILIES COPE AND WHY PoliCMMAKERS NEed TO KNOW 27 (1998); Frade, supra note 8.

57. See PORTUGAL, supra note 6.

58. See Frade, supra note 8 , at $118,164$.

59. See Sónia Costa \& Luísa Farinha, Inquérito à Situação Financeira das Famílias: Metodologia e Principais Resultados, OcCASIONAl PAPER (Banco de Portugal), May 2012, at 31, available at http:/www.bportugal.pt/pt-PT/BdP\%20Publicaes\%20de\%20Investigao/ OP201201.pdf.

The distinction made by Agnès Pitrou should be noted here between promotional solidarity - typical of the middle and upper classes in which kinship networks help the family to enhance their standard of living and rise socially - and subsistence solidarity which is common in the less privileged classes and aims to ensure everyday family life keeps on going. One of the signs of the gravity and extent of the current financial difficulties is the fact that subsistence solidarity has also become vital for the Portuguese middle classes, PORTUGAL, supra note 6.

60. Santos, State, Wage Relations and Social Welfare in the Semiperiphery: The Case of Portugal, supra note 6, at 37; see also João Arriscado Nunes, Com mal ou com bem, aos teus te atém: As solidariedades primárias $e$ os limites da sociedade-providência, 42 REVISTA CRÍTICA DE CIÊNCLAS SOCIAIS 5 (1995), available at http:/www.ces.uc.pt/rccs/ index.php?id=556\&id_lingua $=1$ (discussing the challenges and tensions in the welfare society). 
has been essential for meeting various social needs-ranging from employment and production ${ }^{61}$ to caring for children and the elderly ${ }^{62}$ and providing housing ${ }^{63}$-and helps to fill the gaps in public provision. In this sense, Santos ${ }^{64}$ argues, "in Portugal a weak welfare state coexists with a strong welfare society." In fact, Southern European welfare states ${ }^{65}$ are not included in the Esping-Andersen triptych ${ }^{66}$ and, in the opinion of Ferrera ${ }^{67}$ and Rodes, ${ }^{68}$ form a separate model characterized by the relevance of family support networks and the

61. EUROPEAN COMM'N, supra note 7, at 4; see also Fortunata Piselli, A SociedadeProvidência na Esfera Económica, 42 REvISTA CRíTICA DE CIÊNCLAS SocIAIS 105, 105 (1995), available at http://www.ces.uc.pt/rccs/index.php?id=556\&id_lingua=1; Frade, supra note 8 .

62. Sílvia Portugal, As mãos que embalam o berço: Um estudo sobre redes informais de apoio à maternidade, 42 REVISTA CRÍTICA DE CIÊNCIAS SOCLAIS 155, 157 (1995), available at $\mathrm{http}: / / \mathrm{www}$. ces.uc.pt/rccs/index.php?id=556\&id_lingua $=1$.

63. John Doling \& Richard Ronald, Home Ownership and Asset-based Welfare, $25 \mathrm{~J}$. HoUsING \& BUILT ENV'T 165, 166 (2010); see also Francis G. Castles \& Maurizio Ferrera, Home Ownership and the Welfare State: Is Southern Europe Different?, 1 S. EUR. SOC'Y \& POL. 163, 164 (1996) (discussing the interaction between "private ownership of housing and the public provision of aged pensions").

64. Santos, State, Wage Relations and Social Welfare in the Semiperiphery: The Case of Portugal, supra note 6, at 37.

65. Santos calls Portugal a quasi-welfare state. Having emerged later in comparison to its European peers, the Southern European Welfare State has always shown weaknesses resulting from underfunding, amongst other factors, which has always led to inadequate protection for certain sections of the population and certain types of social and economic risk. $I d$. at 33,34 .

66. See Gøsta EsPing-Andersen, Social Foundations of Postindustrial ECONOMIES 73-94 (1999) (identifying three welfare regimes: conservative (Germany, France and Austria, among others), liberal (U.S., UK and Australia), and socialdemocratic (Scandinavian countries)). See GøSTA ESPING-ANDERSEN, THE ThreE WORLDS OF WELFARE CAPITALISM 1-104 (1990) for Esping-Andersen's premise that these regimes are based on the concepts of decommodification, social stratification, and the distribution of welfare functions among the state, market, and family.

67. Maurizio Ferrera, A reconstrução do Estado social na Europa meridional, 34 ANÁLISE SOCLAL 457 (1999), available at http://analisesocial.ics.ul.pt/documentos/ 1218799082K6bNK0vw3Hi14GU4.pdf; Maurizio Ferrera, The 'Southern Model' of Welfare in Social Europe, 6 J. EUR. SoC. PoL'Y 17, 18 (1996); see also Claude Martin, Social Welfare and the Family in Southern Europe, in SOUTHERn EUROPEAN WELFARE STATES: BETWEEN CRISIS AND REFORM 23 (Martin Rhodes ed., 1997) (arguing that the main typologies of welfare states do not take into account the important role of family in the southern countries).

68. See Martin Rhodes, Southern European Welfare States: Identity, Problems, and Prospects for Reform, 1 S. EUR. SOC'Y \& POL. 1, 10 (1996) (discussing the unique challenges and characteristics of southern welfare states); see also Gallie \& Paugam, supra note 18, at 13 (discussing how the nature of family life impacts de-institutionalism of the traditional family model). 
inadequacy of public provision. ${ }^{69}$ Therefore, this model reproduces and perpetuates the familistic values that historically characterized European Mediterranean societies. ${ }^{70}$

In Southern European countries, familial values still support intergenerational solidarity ${ }^{71}$ and (to a lesser extent) multigenerational and other extended families. ${ }^{72}$ In Mediterranean countries, shared values and representations place great emphasis on strong interpersonal relationships, encouraging interdependency among members of the community and nurturing a sense of belonging and reciprocal sharing. Close ties within the extended family and strong kinship relations are a reflection of that. A recent report from the European Commission confirms this perspective, recognizing that

[t]he countries of southern Europe are characterised by a traditional structure of commitment (in the sense of the normative interweaving of social connections) that can be described as familialist. The stability of familial bonds determines solidarity within the family and plays an overall regulatory role in society. . . . They provide mutual support to one another in accordance with the absolute principle of filial respect towards one's elders

69. This fourth model of the Welfare State is characterised by a combination of the following: a dual system of social protection, polarized between generous protection for those within the labor market (insiders) and weak protection for outsiders (inspired by the pan-professional Bismarckian model); a National Health System governed by the principle of universal citizenship, according to the north European Beveridge model, but which also promotes and fosters the private system; disproportionate protection against social risk, favoring protection for the elderly to the detriment of family and housing support and protection; clientelism in accessing state benefits and support; and family-based solidarity as a security net in the face of inadequate state provision. See generally Ferrera, $A$ reconstrução do Estado social na Europa meridional, supra note 67; Rhodes, supra note 68.

70. According to Sílvia Portugal, "familialist values appear to have a profound effect on social relations in our country and are embedded in individual representations and practices, as well as the legal framework which governs family relations." PORTUGAL, supra note 6, at 27. As an example, the sociologist cites Article 1874 of the Portuguese Civil Code, which establishes that "parents and children owe each other mutual respect, help and assistance." Id.

71. See Anne Revillard, Work/Family Policy in France: From State Familialism to State Feminism?, 20 INT'L J. L. POL'Y \& FAM. 133 (2006), for a discussion on the movement away from familialism and toward women being a major part of the workforce in France.

72. Cf. Ben Mijuskovic, Organic Communities, Atomistic Societies, and Loneliness, 19 J. Soc. \& Soc. WELFARE 147 (1992) (discussing the distinction between the so-called Mediterranean organic communities and the Anglo Saxon atomistic communities, which emphasize individual autonomy). 
and the duty of unfailing protection and care of children. ${ }^{73}$

Solidarity-based mobilization strategies function two different ways. On the one hand, they may emerge from spontaneous action by members of the network who, realizing that a family is facing difficulties, offer them various forms of assistance. This may involve direct financial support (donations, loans, payment of loan installments and of certain goods and services such as rent, public utilities, education) or in-kind support (supplying food, clothing, and footwear). ${ }^{74}$ However, it may also take on a more subtle form (invitations to lunch, dinner, or outings) and be less materialistic (emotional comfort or advice). ${ }^{75}$ On the other hand, solidarity-based mobilization may result from appeals by individuals and households experiencing hardship. In this case, financial support tends to be the main form of aid, in particular the giving of money to pay off debts to financial institutions and service providers. ${ }^{76}$ Whereas "spontaneous solidarity" is accepted naturally, since it does not challenge the beneficiaries' autonomy and self-esteem, "requested solidarity" tends to be seen as more emotionally problematic. Therefore the request is made only in critical situations, such as urgent children's needs, the risk of losing a major asset (for example, the dwelling), or the eminence of bankruptcy. The main reason for the avoidance of requesting help seems to stem from a fear of judgment or attempt of social control from those providing assistance. ${ }^{77}$ Claude Martin explicitly notes that a family gift is accompanied by a "right to interfere," which clashes with the principles of autonomy. ${ }^{78}$

The psychosocial and symbolic aspect of the gift cannot be ignored in countries such as Portugal, where there is a prevailing notion of intergenerational giving, in which resources tend to flow from the older to the younger generations. ${ }^{79}$ This generates inevitable tensions

73. EUROPEAN COMM'N, supra note 7 , at 37 .

74. See Frade, supra note 8, at 118-120.

75. See EUROPEAN COMM'N, supra note 7, at 43.

76. See Frade, supra note 8.

77. See Catarina Frade ET AL., UM PERFil dos sobreendividados em PoRtugal (Catarina Frade ed., 2008). As Sílvia Portugal stresses, "given the intense material and affective flows between parents and children, it is difficult to achieve a balance between giving, reciprocity and autonomy and this become a complex matter for families to deal with." Sílvia Portugal, $O$ que faz mover as redes sociais? Uma análise das normas e dos laços, 79 REvista CRÍTICA DE CIÊNCIAS SocLAIS 35, 49 (2007).

78. Claude Martin, Solidarités familiales: débat scientifique, enjeu politique, in FAIRE OU FAIRE-FAIRE? FAMILLES ET SERVICES 55 (Jean-Claude Kaufmann ed., 1996).

79. Interviews conducted by the European Commission revealed the discomfort and reluctance experienced by parents in Portugal and Spain in accepting help from adult children, primarily because this contradicts the prevailing culture in Southern European 
between the values of the older generations (who tend to be less educated, more conservative, less consumer-driven, and more focused on saving and moderation) and the values of the younger generations (who are more educated, more open to change, and more prone to seek immediate gratification and self-esteem through intensive and complex consumption patterns). ${ }^{80}$ Individuals who have reached higher social and economic status than their parents may experience feelings of shame and denial that prevent them from asking their parents for help. ${ }^{81}$ Besides cutting back on consumption habits, resorting to institutional support mechanisms is the most viable option for those individuals. ${ }^{82}$

\section{Institutional Mobilization}

Institutional mobilization engages with the major institutional actors-the state, the civil society, and the market-and involves opening up the family intimacy to the outside world through the socialization of its inner problems. Mobilizing institutional aid may result from established social alert mechanisms or from the initiatives of individuals facing difficulties.

It includes, amongst other possibilities, various forms of public assistance programs (social policies), such as unemployment benefits, the minimum income allowance, and other forms of social support (for example, student grants, housing subsidies, and children benefits). Currently, the extent and coverage of public support is one of the most critical areas in the architecture of social assistance, given the financial constraints faced by countries such as Portugal, Spain, and Greece. What seems clear, at least in Portugal, is that the general reduction in public support spared the disadvantaged strata of the population more

countries, according to which it is always the parents who should help their children. EUROPEAN COMM'N, supra note 7, at 43. See David J. Cheal, Intergenerational Family Transfers, 45 J. MARRIAGE \& FAM. 805, 806 (1983) (discussing conflicting theories regarding typical nature of intergenerational aid).

80. See Frade, supra note 8 , at 209.

81. Some interviews held in $\mathbf{2 0 0 6}$ reveal this type of emotional reserve and conflict in certain interviewees living in urban areas. $I d$, at 181 .

82. The value placed on individual independence appears to be a defining characteristic of the culture of countries such as France or Germany and helps to explain the greater unwillingness on the part of individuals to mobilise family networks when they face difficulties. In Southern European countries, the tradition of mutual aid amongst less affluent societies which are more accustomed to depending on intergenerational solidarity contrasts with the desire for autonomy and explains why young people leave the family home at a later age (in comparison to the north) and return more readily if they are no longer able to live on their own resources. See EUROPEAN COMM'N, supra note 7 , at 49 . 
than the middle class. With less money to spend and more people needing help, the government has focused on the fight against severe poverty. ${ }^{83}$

Certain judicial and extrajudicial proceedings can also be included in the public sphere, such as the bankruptcy procedures and debt advisory services provided by local authorities and other administrative bodies. ${ }^{84}$ The extrajudicial renegotiation of debts seeks an overall restructuring of the household debts to ensure the payoff of creditors and the retention of property. Nonetheless, debt restructuring only works for those with a regular and sufficient income. ${ }^{85}$ High levels of unemployment therefore compromise the success of such renegotiations. For this reason, many countries enacted bankruptcy laws for individuals, although at great cost to the well-being and quality of life of the individuals and their families. ${ }^{86}$ In effect, most European bankruptcy laws do not prescribe a "fresh start" as broad and generous as the 2005 Bankruptcy Abuse Prevention and Consumer Protection Act. Obtaining debt discharge is far more controlled and uncertain within the context of the European bankruptcy regimes. ${ }^{87}$

Civil society also plays a very important role in the aid to households, namely through various civic, social, and religious nonprofit institutions. With worsening economic conditions in countries such as

83. In the second semester of 2011 , the Portuguese government adopted the Social Emergency Programme, which is directed to the most vulnerable groups of the population. The Social Emergency Programme established "the creation of a solidarity network of social canteens, the Social Rental Market and measures of access to services and equipment (social tariffs for public transports, user fee exemptions in health services, social energy tariffs)." See National Social Report-Portugal, EUROPEAN CoMM'N (May 2012), http://ec.europa.eu/social/BlobServlet?docId=7774\&langId=en.

84. Wolfram Backert et al., Introduction to CONTEMPORARY ISSUES IN CONSUMER BANKRUPTCY 7, 7 (Wolfram Backert et al. eds., 2013); see also Hans Dubois, Household Debt Advisory Services in the European Union, EuRoFound (Apr. 3, 2012), http:/eurofound.europa.eu/sites/default/files/ef_publication/field_ef_document/ef1189en.pd f (identifying what constitutes successful debt counseling and suggesting how to increase access and quality of services).

85. Debt restructuring implies a new framework for reimbursement, usually meaning the adoption of extended repayment periods and/or lower interest rates. Nonetheless, it still requires households to receive minimum regular revenue in order to comply with the new, more feasible contractual conditions.

86. See Wolfram Backert et al., Bankruptcy in Germany: Filing Rates and the People Behind the Numbers, in CONSUMER CREDIT, DEBT \& BANKRUPTCY 273, 286-287 (Johanna Niemi et al. eds., 2009).

87. See Susan Block-Lieb et al., Disclosure as an Imperfect Means for Addressing Overindebtedness: An Empirical Assessment of Comparative Approaches, in CONSUMER CREDIT, DEBT \& BANKRUPTCY 153, 156-162 (Johanna Niemi et al. eds., 2009). See generally Backert, supra note 84 (discussing households' indebtedness, over-indebtedness, and bankruptcy). 
Portugal, requests for aid from households who cannot even meet their daily needs have increased dramatically. Well-known religious and social institutions, such as Caritas, the Food Bank, and the Red Cross, have been providing material support to a growing number of families. ${ }^{88}$

Finally, individuals' applications to financial institutions aiming to renegotiate existing credit agreements or to contract emergency loans also exemplify institutional mobilization, but within the market sphere. The credit issue merits special consideration. Applying for new loans does not always have a positive effect on the household financial situation. Whereas an emergency loan to pay off certain bills and installments may bring immediate relief, empirical data shows that it may, in the medium and long term, make a difficult situation even worse. ${ }^{89}$ Easy access to all sorts of credit products in many countries makes resorting to credit an attractive strategy for those who are drowning in debt. The best example is the credit card which, given its widespread availability, opacity, and dilution over time, may appear to offer a miraculous solution. In short, resorting to credit to pay off accumulated debts or meet everyday consumption needs only functions as an effective coping strategy in a limited number of cases. In most situations, it merely aggravates the existing financial imbalance.

\section{Ambivalence and Variation in Coping Strategies}

The three types of coping strategies are not mutually exclusive and are often combined. The geometry of the combinations varies and depends on several factors related both to the context in which the family lives ${ }^{90}$ and to psychosocial and relational aspects, including the personality traits of the individuals. ${ }^{91}$ Research carried out in $2006^{92}$ has shown that more rural or more urban lifestyles ${ }^{93}$ (corresponding to

88. In 2007, the Portuguese Food Bank assisted over 230,000 people. In 2013, this figure surpassed 350,000 people. Estatísticas: Pessoas Assistidas, FEDERAÇÃO, http://www.bancoalimentar.pt/article/24 (last visited Mar. 2, 2015).

89. A "snowball" effect may occur, resulting in the accumulation of small debts used to pay off other credit commitments in arrears and which very often only helps individuals to slightly reduce the pressure of creditors. See Frade, supra note 8, at 184.

90. See LAZARUS \& FOLKMAN, supra note 41.

91. See Carver et al., supra note 41 , at 272.

92. See Frade, supra note 8 , at 226.

93. According to Edgar \& Sedgwick, "lifestyle referred to the patterns of consumption and use (of material and symbolic goods) associated with different social groups and classes. . . [L]ifestyles may be understood as a focus of group or individual identity, in so far as the individual expresses him or herself through the meaningful choice of certain items or patterns of behaviour, as symbolic codes, from a plurality of possibilities." KEY ConcePts IN Cultural Theory 216 (Andrew Edgar \& Peter Sedgwick eds., 1999). For further discussion, see MICHAEL E. SOBEL, LIFESTYLE AND SOCIAL STRUCTURE: CONCEPTS, 
simpler or more complex consumer profiles), saving habits, the (un)availability of informal support networks, and the diversity of individual and cultural values ${ }^{94}$ (achievement, power, security, conformism) are important predictors of the choices made in coping strategies. For example, households with more sophisticated consumption patterns-mostly those living in urban environments, with higher incomes and education level-found it harder to sacrifice personal consumption but were more willing to resort to institutional solutions. ${ }^{95}$ Contrariwise, in families living in rural areas or on the outskirts of cities-with more frugal consumption habits and lower income, education, and professional qualifications-self-mobilization strategies prevailed, followed by recourse to informal solidarity-based aid. In these cases, institutional mobilization was very rare and considered a personal failure to meet obligations. ${ }^{\mathbf{9 6}}$

There is also a temporal dimension in the interaction between the three types of strategic mobilization. ${ }^{97}$ As previously stated, selfmobilization is the first strategy adopted by households and individuals, and it is also the one that tends to last longer, since it involves selfimposed austerity. However, the severity and the duration of financial problems may require additional forms of support. After households have exhausted their own resources (for example, savings) and adjusted their consumption habits as much as possible without managing to balance their finances, they next resort to informal solidarity-based networks and institutionalized mechanisms. Therefore, a chronological path may be identified among those households that combine the three types of strategies, beginning with self-mobilization, moving on to solidarity-based mobilization, and ending with institutional mobilization. This progression may occur within a shorter or longer period of time but is almost always symptomatic of complex, serious, and persistent financial problems.

Definitions, ANalyses (1981); Pierre Bourdieu, Distinction: A Social Critique of THE JUDGMENT OF TASTE (Richard Nice trans., Routledge \& Kegan Paul Ltd. 1984) (1979); Dieter Bögenhold, Social Inequality and the Sociology of Life Style: Material and Cultural Aspects of Social Stratification, 60 AM. J. ECON. \& Soc. 829 (2001); Mark Tomlinson, Lifestyle and Social Class, 19 EUR. Soc. REV. 97 (2003).

94. Following Schwartz's Values Theory. See Shalom H. Schwartz, Universals in the Content and Structure of Values: Theoretical Advances and Empirical Tests in 20 Countries, 25 AdVANCES EXPERIMENTAL SOC. PSYCHOL. 1, 3 (2003); see also Shalom H. Schwartz, A Proposal for Measuring Value Orientations across Nations, in EUROPEAN SoCIAL SURVEY QUESTIONNAIRE DEVELOPMENT PACKAGE 259, 267 (2003) (U.K.), available at http://www.europeansocialsurvey.org/docs/methodology/core_ess_questionnaire/ESS_ core_questionnaire_human_values.pdf.

95. See Frade, supra note 8, at 179, 232.

96. Id. at 124-26.

97. Id. at $228-29$. 
The progressive path through the three coping strategies cannot, however, be taken as a universal fact. For the strategies to function, each one must be available by itself. Moreover, each has its own limits in terms of coping enablement. For example, the lack of an insolvency procedure suitable for individuals and households in Spain, or the insufficient judicial resources needed to respond promptly to the avalanche of bankruptcies registered in Greece, considerably limits the institutional response in those countries..$^{98}$ Likewise, the exhaustion of solidarity-based networks due to the persistence of the crisis may draw more families into poverty. This is a risk that, above all, threatens the familial societies of Southern Europe, where today it is very common to find several long-term unemployed individuals within the same family circle. ${ }^{99}$ Although kinship networks continue to be effective, there are now more people in need and fewer resources to offer (especially when parental retirement pensions are shrinking). ${ }^{100}$ In addition, sacrifices in consumption may also be restrained by issues of physical survival and emotional stress (translated into anxiety and depressed states).101 Moreover, families, especially those with children, show some resistance in giving up consumption patterns associated to their peer group. ${ }^{102}$ Looking for a new or second job, or working extra hours to compensate for low salaries or lower unemployment benefits, ${ }^{103}$ may also be difficult

98. See Georgios Mentis \& Katerina Pantazatou, Greece, in THE OvER-INDEBTEDNESS of European Consumers: A View From Six CounTries supra note 26, at 19, 62; Pablo Gutiérrez de Cabiedes Hidalgo \& Marta Cantero Gamito, Spain, in THE OvERINDEBTEDNESS OF EUROPEAN CONSUMERS: A VIEW FROM SIX COUNTRIES supra note 26, at $106,129$.

99. See Lopes \& Frade, supra note 54.

100. Paulo Pedroso, Portugal and the Global Crisis: The Impact of Austerity on THE ECONOMY, THE Social Model and the PERformance of THE State 23-24 (Friedrich Ebert Stiftung 2014), available at http://ibrary.fes.de/pdf-files/id/10722.pdf

101. In this context, the results of the European Commission report on the coping strategies of the unemployed are particularly relevant in terms of the levels of selfdeprivation revealed by the unemployed in the seven countries in the study (France, Germany, Portugal, Spain, Ireland, Greece and Romania). The data reveals a clear divide between France and Germany and the other countries. In the first two countries, the families reduced their consumption without this leading to deprivation and poverty. In the other five countries, it involved a genuine struggle for survival and to escape poverty, with individuals reporting lack of food and housing comfort. These results are consistent with those observed in Portugal in research carried out by Frade in 2006. Compare EUROPEAN COMM'N, supra note 7, at 6-8, with Frade, supra note 8, at 177.

102. See Helga DitTMar, The Social Psychology of Material Possessions: To HaVe Is To BE (1992); see also MARY DOUglas \& BARON ISHERWoOD, THE WORLD OF GOODS: TOWARDS AN ANTHROPOLOGY OF CONSUMPTION (2nd ed., Routledge 1996) (1979).

103. The same study highlighted the importance of the informal economy and illegal employment, describing the naturalness with which informal work is viewed in Southern European countries by those who have no alternative if they want to survive. This stands 
or virtually impossible in countries that top the European unemployment ratings, such as Greece, Spain, and Portugal.

\section{EMPIRICAL WORK ON THE COPING STRATEGIES OF COUPLES WITH CHILDREN}

After presenting and discussing the coping strategies' framework employed by households in a financial hardship situation, it is now time to test its validity in the backdrop of the current crisis. Using a set of empirical data gathered in the context of an ongoing research project ${ }^{104}$ and supplemented with indicators taken from other sources, we aim to show the extent to which self-mobilization, solidarity-based mobilization, and institutional-mobilization help, or fail to help, Portuguese households to cope with austerity.

\section{A. Research Question}

The main research question behind this paper asks how Portuguese families with children have mobilized to cope with the crisis. Due to the familist tradition and the so-called welfare society prevailing in Portuguese society, we propose that self-mobilization and intergenerational solidarity is crucial to explain households' adjustments to harsh budget restrictions. As such, those adjustments have been made possible without noticeably compromising overall social stability.

\section{B. Methodology}

Two different analytical tools were used to obtain answers to our research questions: a national survey, covering 1,001 households composed of working age (thirty- to fifty-year-olds) heterosexual couples ${ }^{105}$ with at least one dependent child; and a set of twelve in-depth interviews conducted with couples with the same profile. The survey questionnaire was administered either electronically or in printed

in marked contrast to France and Germany, the two richest countries in the sample. EUROPEAN COMM'N, supra note 7, at 34 .

104. Lina COelho ET AL., FINFAM-Finances, Gender AND POWER: HOW ARE PORTUGUESE FAMILIES MANAGING THEIR FINANCES IN THE CONTEXT OF THE CRISIS? (2015), available at $\mathrm{http}: / / \mathrm{www} . c e s$.uc.pt/projectos/?prj=7416\&id_lingua $=2$.

105. Id. The main focus of the FINFAM project is an analysis of gender-based patterns in financial decision-making by couples, meaning that both the survey and the interviews were restricted to heterosexual couples. 
format between March and August 2014. The face-to-face interviews took place in November and December 2014.

The choice of the target population was based on the expectation that couples with children ${ }^{106}$ were particularly hit by the harmful effects of austerity measures. Moreover, such families have been acquiring a reinforced centrality because of the strong downturn in fertility, leading Portugal to exhibit the second-lowest fertility rate in the world. 107

For the purposes of this study, we selected fourteen of the fifty-four questions from the national survey, involving closed or semiclosed answers. ${ }^{108} \mathrm{We}$ considered questions on the sociodemographic characteristics of the couple and the family, questions directed towards identifying changes that took place in the lives of families as a result of the economic crisis (changes in professional status and income, spending habits, indebtedness, and savings), and questions about the role of informal solidarity-based social networks (giving versus receiving).

In this context, the main purposes of the twelve in-depth interviews were to: (a) obtain a deeper understanding of the qualitative aspects of the households' adjustment strategies to the crisis; (b) explore how the specific characteristics of families and the respective social and relational contexts impact the strategies undertaken, and; (c) identify overlapping or sequencing in the strategies adopted. Thus, the interviews focused on some of the most critical problems addressed in the questionnaire.

\section{Sociodemographic Characteristics}

There were four sociodemographic variables selected: age of the spouses, professional status, level of education, and net monthly income of the household.

106. In 2011, this type of household represented $35.2 \%$ of the $4,048,559$ families in the country, with the total population standing at 10,562,178. Statistics Portugalhttp://censos.ine.pt/xportal/xmain?xpid=CENSOS\&xpgid= censos2011_apresentacao (last visited Mar. 4, 2015).

107. See United Nations Population Fund [UNFPA], The Power of 1.8 Billion: Adolescents, Youth and the Transformation of the Future, THE STATE OF WORLD POPULATION 2014, at 107 (2014).

108. For a more detailed description of this analytical tool, see LINA D. CoELHO ET AL., Finances, Gender AND Power: How aRe PoRTuguese Households MaNaging Their FINANCES IN THE CONTEXT OF ECONOMIC CRISES? (Apr. 1, 2014), auailable at http://www.ces.uc.pt/myces/UserFiles/livros/1097_Relatorio_1_FINFAM_Versao_1_Abril20 14.pdf. 


\section{Changes in Professional Status and Household Income}

To assess the effects of the crisis, two of the questions asked the participants to state whether there have been changes to the professional status and income of the household (remained the same, increased or decreased, by a large or small amount) for the past three years.

\section{Changes in Expenditure Patterns and Budget Adjustments}

Two of the questions asked the participants to indicate, from a short list of items, changes that occurred in household expenditure during the past three years (housing comfort, food, clothing, utilities, transports, healthcare, education, culture, insurance, and leisure activities).

\section{Changes in Savings and Indebtedness}

Three questions asked the respondents whether the household was paying installments on loans and, if so, what kinds of loans (housing, car, consumer items, credit card, etc.). They were also asked whether, in the past three years, the family had delayed paying any installments or had increased indebtedness to meet daily needs. In this case, they were also asked about the type of institution to whom they owe money (bank, other financial institution, family, friends, employer).

\section{Support from Informal Social Networks}

Two questions asked respondents to state whether, in the past three years, the family had received or given goods or money regularly to people outside the household (parents, siblings, children, friends, others). If so, they were asked whether the levels of exchange remained the same, increased, or decreased (by a large or small amount).

\section{Presentation and Discussion of Results}

The average age of the respondents was 40.4 for women and 42.2 for men. Most respondents were salaried workers ( 74.5 percent) and worked full time (83 percent and 76 percent, respectively, for men and women). Both partners were employed in 72.2 percent of the cases. However, at least one of the partners was unemployed in 18.7 percent of 
the couples (female unemployment: 9.2 percent; male unemployment: 7.8 percent; both unemployed: 1.7 percent). ${ }^{109}$

Regarding education, 20.6 percent were educated to International Standard Classification of Education (ISCED) level one ${ }^{110}$ or below, 21.7 percent to level two, 28 percent to level three, and the remaining 29.8 percent at higher levels. There was homogeneity in couples' education in approximately half of the sample, whereas women had a higher level of education in 33.7 percent of the couples.

More than 56 percent of the households had a monthly income of 1,400 euros or less, and 12.1 percent received less than 700 euros. Only 10.8 percent had an income higher than 2,500 euros. The percentage of households living below the poverty line was 16.4. Most respondents (71.5 percent) claimed to have suffered a drop in income during the last three years (38.1 percent, a sharp drop; 33.4 percent, a very sharp drop). Only 20.3 percent reported unchanged income. Three in four households had loans (73.5 percent), 86.7 percent of which were for housing.

\section{Coping by Self-Mobilization}

As a result of the crisis, the majority of the surveyed households were forced to reduce their budgets (68.1 percent). Hence, a general cut in family spending was observed, as well as a redefinition of consumption habits. The results show a clear pattern of choices, with households attempting to hold on to expenses deemed essential (food, accommodation and related expenses, children's education, and healthcare) (Table 1). Accordingly, households opted to sacrifice expenditures regarded as dispensable, such as holidays, leisure activities, restaurant outings, and other items such as clothing, furniture, and household appliances. ${ }^{111}$

\footnotetext{
109. There were also a few persons with a different professional status (students, housekeepers and pensioners).

110. ISCED: International Standard Classification of Education, UNESCO INSTITUTE FOR STATISTICS, http://www.uis.unesco.org/Education/Pages/international-standardclassification-of-education.aspx (last visited Mar. 4, 2015).

111. It should be noted that expenses on housing (rent or loan instalments) and other loans are not included here since they involve fixed, contractual amounts. This problem will be analysed later in the context of the discussion of the mobilization of solidaritybased and institutional help regarding the management of family debts.
} 
Table 1. Ranking of cuts in household expenditure

\begin{tabular}{|l|l|}
\hline Categories & $\begin{array}{l}\text { Households who cut spending } \\
\mathbf{2 0 1 0 - 2 0 1 4}(\%)\end{array}$ \\
\hline Restaurants & 84.3 \\
Holidays and travel & 79.5 \\
Other leisure activities & 77.4 \\
Household appliances and furniture & 66.0 \\
Clothing & 65.4 \\
Domestic services & 54.4 \\
Support for dependent persons & 44.4 \\
Transport and fuel & 37.4 \\
Telephone, internet & 37.1 \\
Insurance & 29.0 \\
Food & 23.3 \\
Electricity, gas and water & 19.7 \\
Healthcare & 13.5 \\
Children's education & 12.3 \\
\hline
\end{tabular}

Source: FINFAM, own calculations.

The interviews confirmed the aforementioned priorities in household spending. In addition, they revealed some more qualitative aspects of the choices made, such as changes in shopping locations in search for cheaper or discount products.

I had my life, our life, organized around two good salaries. At the moment, I get an average salary and my husband gets a salary that [depending on the month] might be considered good, average or low. So, now we have to deal with certain changes. ... We have to give some things up. We'll have to do without things we don't need. For example, expensive clothes, expensive shoes. . . . But not things for the children, no! We'll try to keep giving them the best we can. But we'll have to do without. ... No more going to the hairdresser... . I used to get lunch out every day. Now, I bring my own food. . . . I just buy a coffee. . . . I used to do all the monthly shopping in the same place, regardless of whether it was cheaper or more expensive. ... Not anymore. Now I look around and try to find the cheapest place ... something 
I never used to do. I look out for coupons and promotions ... anything to keep costs down.

-Woman, aged forty, IT technician, two children, urban area.

Look, I didn't exceed. . . . I got shirts for just three or four euros. I got leggings for five euros and a pair of jeans for seven euros. . . I bought two pairs of sneakers, but no boots.

-Woman, aged forty-three, dressmaker, two children, rural area.

There are some days we just eat soup. Soup, soup, soup. ... With no meat . . [The children] sometimes don't want to . . but what can we do? They eat it up in the end, don't they? Or potatoes, because we've got a small plot, that's how we get through. We've got potatoes, onions, cabbages. ... It's how we get through ... And sometimes there's an egg when the hens lay them, well. . . Sometimes we eat, sometimes we don't. We only eat potatoes and cabbage, that's it. That's the way it is.

-Woman, aged forty-two, housewife, three children, rural area.

One of the changes to everyday life highlighted in the answers relates to the workers' lunchtime habits. In Portugal, due to the intense participation of women in the labor market, lunch has ceased to be a family affair and has become a time for socializing around the table with work mates. ${ }^{112}$ This has led to the emergence of a large number of small restaurants specializing in cheap, traditional meals (soup, fish or meat dish, and dessert). Wage cuts, together with an increase in the value-added tax (VAT) on catering services (from 13 percent to 23 percent), have profoundly changed this habit. Many workers have replaced meals in restaurants with a lunch box (40.5 percent of respondents to the aforementioned survey reported adopting this practice). To accommodate this change, some employers have begun to offer small spaces in the workplace equipped with a microwave for that purpose.

112. See Maria Paula Mascarenhas, Sociabilidades Em Volta da Mesa 5 (June 2012) (paper presented at the VII Congresso Português de Sociologia, University of Porto), available at $\mathrm{http}: / /$ repositorium.sdum.uminho.pt/bitstream/1822/24763/1/Sociabilidades\% $20 \mathrm{em} \% 20$ volta $\% 20$ da $\% 20$ mesa.pdf. 
Sacrifices in spending habits can also be interpreted from a gender perspective. Some of the categories subjected to the deepest cuts correspond to tasks traditionally carried out by women within the family, in accordance with traditional gender roles. Those include care for the elderly and disabled, domestic tasks, and preparation of meals (the reduction in restaurant spending implies the need to feed the lunch box).

[The cleaning lady] was one of the things we had to cut. It's one of the things I regret the most. ... It was a great help ... those were tasks I wouldn't do and so I had more time to be with the children. I lost that, and I feel sad about it. . . . I just lay them in bed and then I think ... hell, I didn't even have time today to sit down for a little bit and play with them. Only at weekends, only at weekends.

-Woman, aged forty, IT technician, two children, urban area.

We always bring our own lunch to eat at work. . . Lots of people do.

-Man, aged forty-two, engineer, two children, urban area.

Despite reducing spending and reorganizing budgets, around half of the respondents (50.7 percent) stated they had to resort to savings to deal with current expenses and bills. However, this is the kind of resource that cannot last forever. In fact, 62.4 percent of households have declared a reduction in their savings for the past three years.

In relation to savings, things have stagnated.

-Man, aged forty-four, bank employee, one child, urban area.

Furthermore, many self-mobilization measures have been unavailable, including some related to the labor market. For example, only 8.8 percent of the respondents stated that they had taken on extra work time. Moreover, although 22.4 percent stated they had increased working hours, this does not necessarily mean the increase was voluntary. In fact, in 2013 the government raised the mandatory weekly working hours of civil servants, from thirty-five to forty hours, whilst maintaining wage cuts in force since 2011. Thus, the increase in 
working hours does not necessarily represent a coping measure for dealing with family budget restrictions.

For some interviewees, emigration is envisaged as an eventual strategy to cope with the hardship, either for themselves or for their children's future.

That is why we have to emigrate. My daughter went out to Switzerland last year. Some of my brothers are there. And we'll probably do the same because of the way things are here.... There's no work, we look for it but the answer is always a no. We really have to emigrate.

-Woman, aged forty-two, housewife, three children, rural area.

So, [my daughter] has to get a degree and then think about emigrating, like everyone else. That's the way life is, that's the kind of country we're living in. We educate our youngsters and other countries get the benefit of that. That's the way things are now.

-Man, aged forty-six, prison warder, one child, urban area.

In a context of budget restructuring, Portuguese households give priority to fulfilling loan repayment obligations, as clearly revealed in a cross-country analysis recently published by the European Union. ${ }^{113}$ In our sample, 73.3 percent of the respondents stated they were paying off loans, ${ }^{114}$ but only 13.2 percent declared to have been in arrears with any installment.

Well, usually it is like this. . . . On the 23rd, the installments come up for the house, the car, such kinds of things. I pay those first bills straight away, out of my salary. Then, his salary comes in on the 30th, which helps to manage the budget. We haven't been able to save anything recently ... nothing. . . . Indeed, my

113. See EUROPEAN COMM'N, supra note 7, at 14.

114. Although this figure is more than double the national average $(37.7 \%$ in 2010 , according to the Bank of Portugal) this is due to the fact that our sample corresponds to the profile of a family which, in comparative terms, makes greater use of credit (adults of working age, with children). Sónia Costa \& Luísa Farinha, O endividamento das famílias: Uma análise microeconómica com base nos resultados do Inquérito à Situação Financeira das Famílias, in RELATóRIO DE EsTABILIDADE FINANCEIRA, 137, 143 (2012). 
salary is used for our [fixed] expenses. The rest . . . his wage, is for us to live on during the whole month.

-Woman, aged forty, IT technician, two children, urban area.

My [main] concern is not to owe anything to anyone. . . . Being able to pay the bills and have something left over is a very good thing, I'd say, honestly.

-Man, aged thirty-six, café owner, one child, rural area.

\section{Coping by Solidarity-Based Mobilization}

During the current financial crisis, solidarity-based mobilization has been playing a key role in helping households' adjust to financial hardship.

According to the empirical data obtained, 28.1 percent of the households received money or goods on a regular basis. For almost three-quarters of the households, help was provided by the parents of one of the partners, with some households receiving help from both sets of parents. Siblings were the second most common source of assistance (13.9 percent), followed by friends ( 11.4 percent). In our sample, the highest percentage of households receiving that kind of economic help fell within the group with both partners unemployed (42.1 percent), followed by households with only one of the partners working full time (approximately 33 percent). Moreover, the aid received was inversely proportional to the household income (38.5 percent of couples who received aid earned a monthly income of less than 700 euros, as opposed to 10 percent of couples whose income ranged from 3,500 to 5,000 euros).

My father gives me an allowance. Which is not cheap. Because I, up to a short while ago, I had some savings. So I have to organize things well. . . . I wouldn't be able to survive ... it's not have a living, it's managing to survive, indeed ... with just what I was earning.

-Woman, aged forty-three, acupuncturist, one child, urban area.

When my deceased mother was still with us things were much better ... because there was another wage coming in [the retirement pension].

-Woman, aged forty-two, housewife, three children, rural area. 
The interviews revealed that intergenerational aid is not always monetary; it often is in-kind aid. Usually it includes looking after grandchildren, providing meals, or giving products from family plots.

My mother or my father. . . . My father is now retired and very often they even go together. To pick up my daughter, or take her, depending on my shift. They are a great help that way. And, currently, as my husband is working nearby, when I can't cook lunch he is going to have lunch at my mother's because she also lives nearby. ... And that really is a big help.

-Woman, aged forty-three, care assistant to the elderly, one child, urban zone.

His mother brings us home-grown stuff when she can. ... She brings lemons, garlic.

-Woman, aged thirty-six, hospital cleaning worker, four children, urban zone.

My mother pays for a cleaning lady to come to us three hours a week.

-Woman, aged thirty-four, scientific research manager, two children, urban zone.

Another significant feature of solidarity-based strategies is the role of kinship networks in providing funds. That was the case for 30.5 percent of the households in the survey who were forced deeper into debt in order to meet consumer needs or other obligations, including loan installments. In 57.3 percent of such cases, family members provided funds, thus exceeding banking institutions (49.6 percent). That means "solidarity funding" has been bridging the restrictions on credit availability imposed by the financial institutions under the fiscal adjustment policy in the context of the 2011 Economic and Financial Assistance Program.

\section{Coping by Institutional Mobilization}

In Southern European societies, levels of trust in official institutions are traditionally low. ${ }^{115}$ However, the crisis has deepened the lack of

115. See European Commission, Directorate-General for Communication, Standard Eurobarometer 80, Public Opinion in the European Union: First Results, at 5 (Dec. 2013), available at http:/ec.europa.eu/public_opinion/archives/eb/eb80/eb80_first_en.pdf. 
confidence in state and financial institutions, as confirmed both by the aforementioned European Commission Report and our own interviews.

Because people no longer trust the banks. . . . We don't trust anyone anymore, basically. There's very little trust in those people. Moreover, I don't know what it will be like with this crisis. I simply don't believe anything they say. . . They can be from the left, the far left, the far right - it's all the same to me. . . . I don't really trust them [the politicians]. So we always have to wait and see what happens.

-Man, aged forty-six, prison warder, one child, urban area

In an overall context of increasing distrust of state bodies and financial institutions, the dynamics of institutional coping strategies proved ambivalent. The cuts to various forms of public assistance we have described have limited even more welfare state provisioning. ${ }^{116}$ The same notion applies to bank loans as a means of compensating for falling incomes and social benefits. Still, some strategies of institutional mobilization, such as the use of the bankruptcy procedures, have become significant following the crisis.

The renegotiation of the contractual terms of loans with financial institutions, which is a classic coping strategy, does not feature highly in our data. Only one interviewee said he had arranged an extended repayment period for a bank loan to reduce monthly installments.

We chose to change the loan and spread it out longer to bring down the installments.

-Woman, aged forty-three, seamstress, two children, rural zone.

According to our survey, 18.1 percent of the households had to delay credit repayments in the last three years. Some households rotate repayments of various loans and other debts to face difficulties and

116. In the second half of 2011 the government adopted a Social Emergency Programme, through which certain forms of social assistance were created for the neediest families, including social tariffs for water, electricity and transport, subsidised canteens and rent, a $10 \%$ increase in unemployment benefit for couples with children when both partners were unemployed, etc. See Governo de Portugal, Programa de Emergência Social, available at http://www.portugal.gov.pt/media/747090/programa\%20emergencia\%20social.pdf (last visited Mar. 2, 2015). 
avoid full default. However, many still end up completely losing control of their finances, since arrears tend to accumulate.

Now, above all, as my husband is off work, sick, it's very difficult. Very. . . . I've got some bills I haven't managed to pay. . . . I always pay the latest one, always the latest. ... So the latest is always in stock. ... I do this way because otherwise ... it is very hard, very difficult.

-Woman, aged forty-two, housekeeper, three children, rural zone.

Our data shows that around 20 percent of the households dealt with difficulties by applying for new loans from the credit market. Extant studies have shown that resorting to credit to pay off previous debts is mainly accomplished by more frequent use of credit cards, overdraft facilities, and taking out small personal loans. Such types of credit usually involve higher interest rates. ${ }^{117}$ Therefore, the risk of family bankruptcy increases.

As a rule we always use the overdraft to pay the installment on the house.

-Woman, aged forty-three, seamstress, two children, rural zone.

As initially noted, data on bankruptcy trends in Portugal is very symptomatic of households' economic decline. After a near absence of bankruptcy cases prior to the start of the crisis (in 2007, there were only 529 declarations of bankruptcy of natural persons), there was a burst of new cases and, in 2013 alone, 11,409 people declared bankruptcy. ${ }^{118}$ Although the 2004 Insolvency Code is not particularly generous to individuals-almost every asset (including dwellings) may be seized and access to debt discharge is quite difficult-the lack of effective legal alternatives, 119 the shrinking social policies, and the growing pressure

117. See FRADE ET AL., supra note 77, at 50; see also Frade, supra note 8, at 23.

118. Authors' own calculations based on statistical information issued by Direcção-Geral da Política de Justiça. See generally Highlights, Direcçāo-Geral Da Polf́fiCA De JustiçA, http://www.dgpj.mj.pt/sections/siej_pt/destaques4485 (last visited Mar. 2, 2015) (using quarterly statistics on insolvency proceedings, bankruptcy and business recovery and revitalization of special processes for 2007-2013 in Q1, Q2, Q3, and Q4).

119. In 2012 a package of legislative measures was adopted which, amongst other things, aimed to establish procedures for the extrajudicial renegotiation of debts contracted with credit institutions. It included the system known as PERSI. For further information on this and other legal measures aimed at families in financial difficulty, see Frade \& Almeida, supra note 26, at 66, 76. 
on formal and informal solidarity networks ${ }^{120}$ have left many households with no solution other than filing for bankruptcy.

\section{CONCLUSION}

Portuguese families' well-being has been severely hit by the harsh effects of the crisis, as we have documented in this paper. Still, households managed to meet most of their contractual obligations. The relatively moderate figures for credit and utility bill arrears, and even for bankruptcy of individual persons, can be mostly explained through informal and inconspicuous adjustment procedures. These procedures emerge out of a strong social solidarity network, which is embedded in the overall social regulation model of the country.

The empirical research reveals a predisposition of people toward resignation and even fatalistic acceptance of impoverishment and downsizing of future life perspectives.

Families appear highly willing to sacrifice consumption, even with basic needs. Sacrifices are made, above all, in the name of two binding responsibilities inherent to the prevailing social representation of the family: the well-being of children and the protection of the family home.

By its key role in overcoming or alleviating the impacts of the crisis, gifts have retaken a central, actual function in strengthening social ties. 121

In a context of shrinking welfare state and growing distrust of institutions, the Portuguese welfare society has been forced to regain a leading role as welfare provider and social regulation mechanism.

120. See id. at 80-83. Various charitable institutions, such as Caritas, the Food Bank and other NGOs, responding to social emergencies have been involved in intensive work to provide material support for families. Several heads of these organisations have reported increasing requests for aid, particularly from middle class individuals and families. The Food Bank, for example, supported approximately 230 thousand people in 2007, whereas in 2013 the figure had risen to 350 thousand. See Estatísticas: Pessoas Assistidas, supra note 88 .

121. See GodBoUT, supra note 55; CAILLÉ, supra note 55. 